\title{
The Relationship between Body Condition and Milk Composition in Dairy Goats
}

\author{
Myrtill Gráff ${ }^{1}$, Edit Mikó ${ }^{1}$, Bence Zádori ${ }^{1}$, József Csanádi ${ }^{2}$ \\ ${ }^{1}$ University of Szeged Faculty of Agriculture, 15 Andrassy street, Hódmezővásárhely, Hungary \\ ${ }^{2}$ University of Szeged Faculty of Engineering, Szeged, Hungary
}

\begin{abstract}
A total of 46 Swiss alpine does were examined. We analysed the composition of the milk and evaluated the body condition of the animals (BCS: 0.5 to 4.5 scale) on the same day in the last third of lactation. Goats were grouped according to their body condition for statistical calculations. We found that there was a statistically detectable relationship between body condition and milk composition of the goats. Together with the increase of BCS, the fat, protein and mineral contents in the milk increased as well. Significantly more fat, protein and mineral contents were found in the milk $(6.01 \% ; 3.55 \% ; 0,98 \%)$ in case of the well-conditioned (BCS 3.5) animals than in the thin ones (BCS $1.5-2)(4.56 \%, 3.11 \%, 0.77 \%)(P<5 \%)$. The concentration of milk sugar was similar between thin and better conditioned groups of animals, so the body condition did not affect these values. The importance of our study is that, the high fat and protein content of milk increases the yield of dairy products. If the animals can produce milk that has higher fat and protein content, than we can produce more dairy products that will bring more economic benefits. The aim of our study was to evaluate the effects of body condition on milk yield and quality (milk composition) in dairy goats.
\end{abstract}

Key words: goat, milk composition, body condition, milk fat, milk protein.

\section{Introduction}

Despite the world-wide importance of goats as sources of essential meat and dairy products $[1,2,3]$, less research is performed on them than on cattle and sheep. There is also little data available to examine the relationship between body condition and milk composition in goats. The importance of our study is that, the high dry matter content of milk (mainly milk fat, milk protein) increases the cheese yield [4]. Minerals in milk and dairy products contribute to healthy human nutrition [5].

Inadequate nutrition of animals can result in a marked decrease in milk yield. In addition, the poor nutrition may result low milk fat and protein

\footnotetext{
* Corresponding author: Myrtill Gráff, graff@mgk.u-szeged.hu
}

\section{(cc) BY-NC-ND ( 2018 Myrtill Gráff et al., published by Sciendo}

content and abrupt changes of body condition score (BCS) [6]. Milk is produced from nutrients in the blood. These nutrients are taken by the milky gland and the gland makes the milk from these raw materials. So, high-nutritious milk can be formed just with good nutrition. There is no link between genotype and milk yield, milk composition between the different genotypes of Sarda goats. [7]. The milk fat concentrations are similar between thin animals (low BCS) and animals with good body condition, whereas milk protein concentrations are different significantly between thin and animals in good body condition [8]. Animal body condition is considered as an indicator of fat reserves [9].

The aim of our study was to evaluate the effects of body condition on milk yield and quality (milk composition) in dairy goats. 


\section{Material and Methods}

The study was carried out on 46 Swiss alpine does on a farm in Hungary. The age of livestock was mixed, between 4 and 11 years old. In fact, the number of parities is the same as age, since goats are pregnant at 9 months of age for the first time and the duration of pregnancy is 5 months. There is a goat house, where the does, two bucks, the milking room are located. The does have milking twice a day, morning and evening. The animals graze the pasture all day long. The pasture is of good quality, which is a plain, along a river. Animals received $0,60 \mathrm{~kg}$ of fodder (barley, wheat, corn), during milking. They get alfalfa hay, grass hay- ad libitum, in the goat house too.

We analysed the milk composition and determined the body condition scores of the animals (BCS; scale $0,5-4,5$ ) on the same day (13th) in September, in the last third of the lactation. Goats were grouped according to their body condition for statistical calculations and the values were depicted on a graph. The dry-matter content of milk, protein, fat and milk sugar were measured in $\mathrm{m} / \mathrm{m} \%$, using Bentley 150 IR type milk analyser (Peavey Rd, Chaska, Minnesota 55318; USA). The amount of minerals is an informative value as it is estimated by its own calibration. The values given are averages of 2 parallel measurements. Data collected were registered on a Microsoft Excel worksheet and statistically analysed by using SPSS (Statistical Package for Social Sciences) version 22.

\section{Results and Discussions}

There is a significant difference between the milk protein content in the milk of thin goats (BCS 1.52 ) and that of the well-conditioned goats (BCS 3.5). The content of milk protein increased with improved body condition (Fig. 1.).

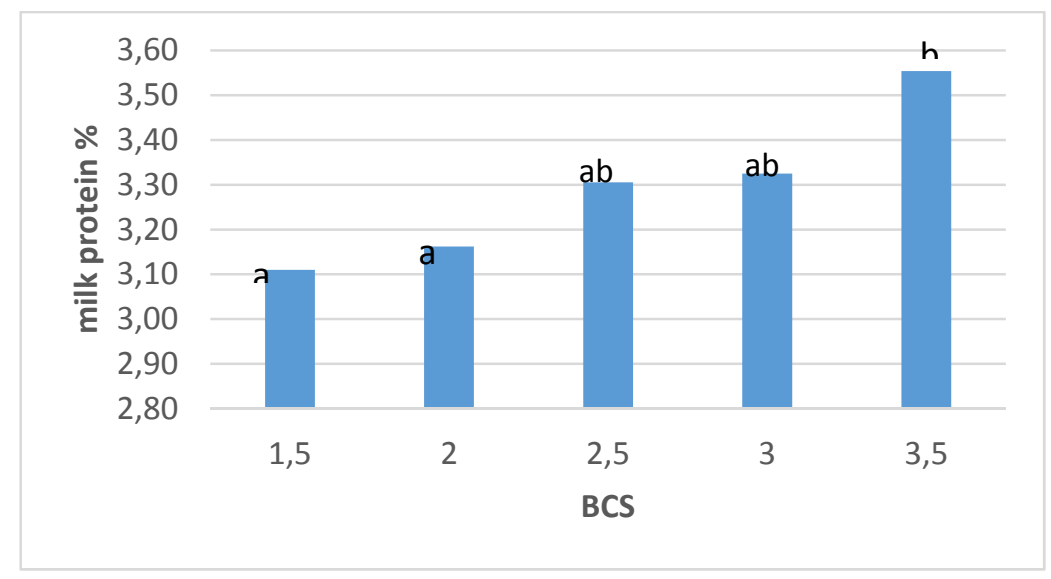

The means marked with different letters are significantly different $P<5 \%$

Fig. 1. Relationship between body condition and milk protein

The fat content of the milk (Fig. 2.) was significantly higher (milk fat $6 \%$ ) in goats with BCS
3.5 , than in those with poor condition (milk fat $\%$ 4,6; BCS 1,5-2).

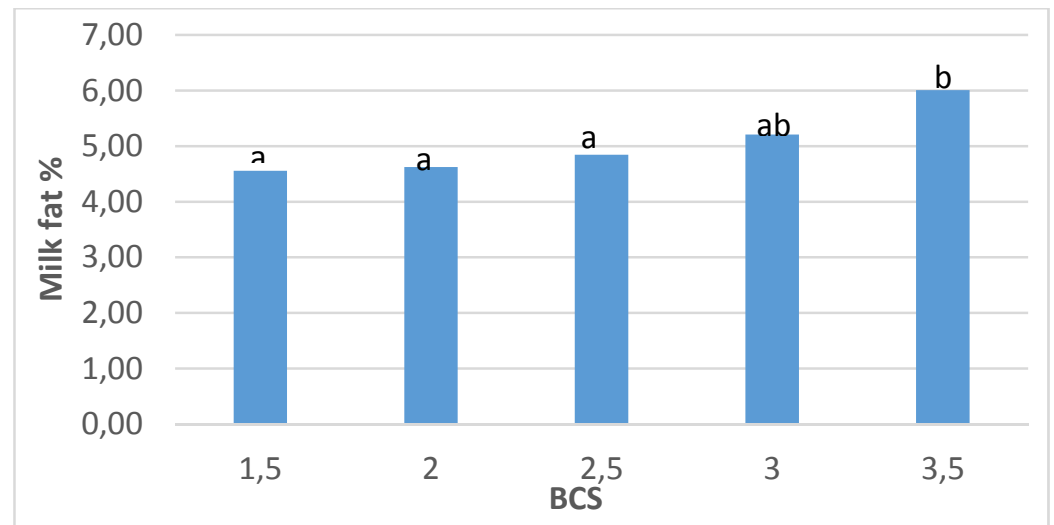

The means marked with different letters are significantly different $P<5 \%$

Fig. 2. Relationship between body condition and milk fat 
There was also a significant difference between the mineral content of the milk and the body condition (Fig. 3.). The mineral content in the milk was $0,77 \%$ at BCS 1.5 while it was $0.98 \%$ at BCS 3,5 .
The sugar content of the milk did not change depending on the body condition of the animals. Significant differences cannot be detected in any of the groups (Fig. 4.). The values ranged from 4.56 to $4.66 \%$.

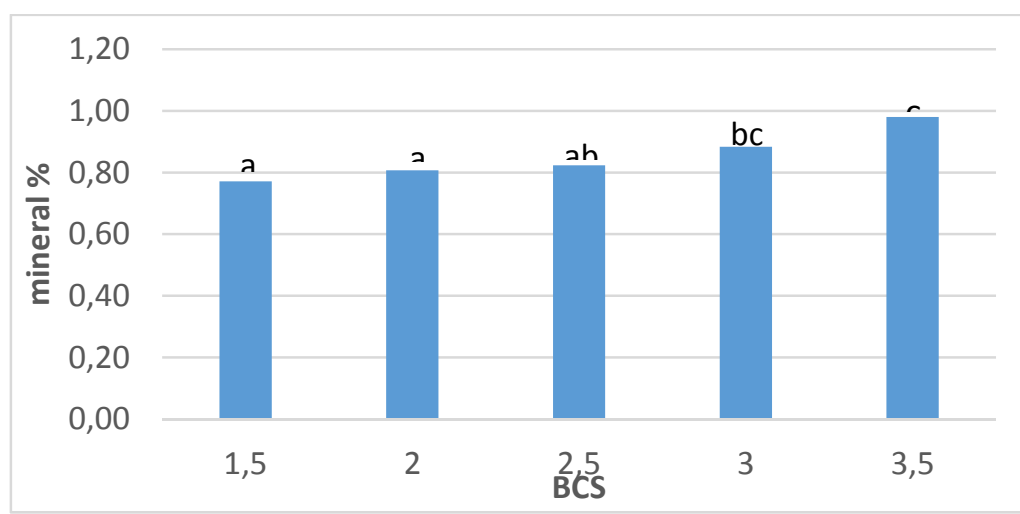

The means marked with different letters are significantly different $P<5 \%$

Fig. 3. Relationship between body condition and minerals in milk

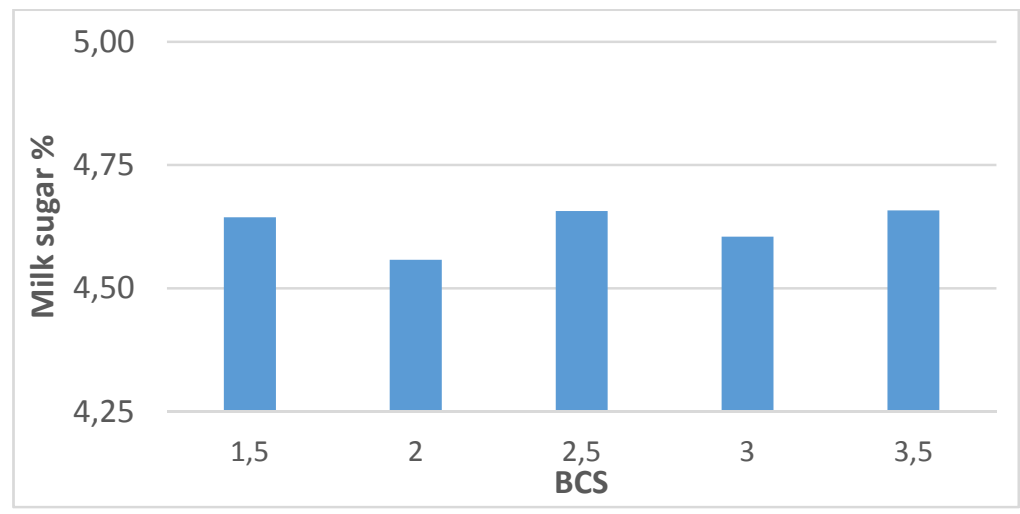

Fig. 4. Relationship between body condition and milk sugar

Significantly more fat, protein and mineral contents were found in the milk $(6.01 \% ; 3.55 \%$; $0,98 \%$ ) in case of the well-conditioned (BCS 3.5) animals than in the thin ones (BCS 1.5-2) $(4.56 \%$, $3.11 \%, 0.77 \%)$. The concentration of milk sugar was similar between thin and better conditioned groups of animals, so the body condition did not affect these values. In contrast to our results, in the study of Busato et al. [8] the amount of milk fat was similar between the different groups of different body conditions, while in the case of milk protein, they also found significant differences. However, the nutrient content of the goat-milk does not only depend on body condition, but also on feeding, variety and season [10].

\section{Conclusions}

Overall, we can conclude that there was a statistically detectable relationship between the body condition and the milk composition of the goats. Together with the increase of BCS, the fat, protein and mineral contents in the milk increased as well. The body condition did not affect the concentration of milk sugar.

\section{References}

1. Morand-Fehr, P., Boutonnet, J.P., Devendra, C., Dubeuf ,J.P., Haenlein, G., Holst, P., Mowlem, L., \& Capote, J. (2004). Strategy for goat farming in the 21st century. Small Ruminant Research, 51 , 175-183 https://doi.org/10.1016/i.smallrumres.2003.08.013 
2. Dubeuf, J.P., Morand-Fehr, P. \& Rubino, R. (2004). Situation, changes and future of goat industry around the world. Small Ruminant Research, 51, 165173 ,

https://doi.org/10.1016/j.smallrumres.2003.08.007 3. Morand-Fehr, P. \& Lebbie S.H.B. (2004). Proposals for improving the research efficiency in goats. Small Ruminant Research, 51, 145-153, https://doi.org/10.1016/j.smallrumres.2003.08.012

4. Alendri, A., Buttazzoni, L.G., Schneider, J.C., Caroli, A. \& Davoli, R. (1990). The Effects of Milk Protein Polymorphisms on Milk Components and Cheese-Producing Ability. Journal Dairy Science, 73, 241-255,

https://doi.org/10.3168/jds.S0022-0302(90)78667$\frac{5}{5}$

5. Lante, A., Lomolino, G., Cagnin, M. \& Spettoli, P. (2006). Content and characterisation of minerals in milk and in Crescenza and Squacquerone Italian fresh cheeses by ICP-OES. Elsevier Food Control, 17 , 229-233, https://doi.org/10.1016/j.foodcont.2004.10.010

6. Branca, A. \& Casu, S. (1989). Body condition score annual evolution and its relationship with body reserves in Sarda goat, 215-231, in: L'évaluation des ovins et des caprins méditerranéens, Symposium "Philoetios", Flamant J.C., Morand-Fehr P. (eds.), Rapport EUR 11893, Luxembourg: Opoce

7. Vacca, G.M., Ouled, H., Pazzola, M., Dettori, M.L. \& Carcangiu, V. (2009). An investigation on allele frequency at the CSN1S2 locus and its relationship with milk parameters in the Sarda goat. Journal of Animal Sciences, 18,

628-637, https://doi.org/10.22358/jafs/66437/2009

8. Busato, A., Faissler, D., Küpfer, U. \& Blum, J.W. (2002). Body Condition Scores in Dairy Cows: Associations with Metabolic and Endocrine Changes in Healthy Dairy Cows. Transboundary and Emerging Diseases, 49, 455-460, https://doi.org/10.1046/j.14390442.2002.00476.x

$9 . \quad$ Russel, A.F.J., Doney, J.M. \& Gunn, R.G. (1969). Subjective assessment of body fat in live sheep. Journal Agricultural Sciences, 72, 451-454, https://doi.org/10.1017/S002185960002487

10. Pandya, A.J. \& Ghodke, K.M. (2007). Goat and sheep milk products other than cheeses and yoghurt. Small Ruminant Research, 68, 193-206, https://doi.org/10.1016/j.smallrumres.2006.09.007. 